\title{
PUTUSAN PENINJAUAN KEMBALI PERKARA PIDANA SEBAGAI NOVUM DALAM PENINJAUAN KEMBALI PERKARA PERDATA
}

\author{
Kajian Putusan Nomor 119PK/Pdt.Sus-HKI/2017 dan Nomor 104PK/Pid.Sus/2015
}

\section{DECISION OF A CRIMINAL CASE REVIEW AS NOVUM IN A CIVIL CASE REVIEW}

\author{
An Analysis of Court Decision Number 119PK/Pdt.Sus-HKI/2017 \\ and Number 104PK/Pid.Sus/2015
}

\begin{abstract}
Ali Marwan Hasibuan
Kantor Wilayah Kementerian Hukum dan HAM Sumatera Utara

Jl. Putri Hijau Nomor 4 Medan 20111

Email: ali_marwan@rocketmail.com atau ali.marwan13@gmail.com
\end{abstract}

Naskah diterima: 26 Juli 2018; revisi: 1 April 2019; disetujui: 2 Mei 2019

http://dx.doi.org/10.29123/jy.v12i1.327

\begin{abstract}
ABSTRAK
Undang-Undang Nomor 15 Tahun 2001 tentang Merek mengatur bahwa untuk penyelesaian sengketa atau pelanggaran merek dapat ditempuh melalui dua alternatif penyelesaian, yaitu dengan mengajukan gugatan ke pengadilan niaga (secara perdata) dan diadukan kepada penyidik untuk diselesaikan secara pidana. Kedua penyelesaian inilah yang ditempuh sekaligus oleh GG melawan GB. Kasus ini kemudian sampai pada upaya hukum luar biasa yaitu peninjauan kembali. Dalam peninjauan kembali perkara perdata, pihak GG mengajukan putusan peninjauan kembali perkara pidana sebagai novum. Berdasarkan hal tersebut, dapat dirumuskan permasalahan dalam tulisan ini adalah: apakah putusan peninjauan kembali perkara pidana dapat dijadikan novum dalam peninjauan kembali perkara perdata? Metode penelitian yang digunakan dalam tulisan ini adalah metode penelitian yuridis normatif atau metode penelitian kepustakaan. Hasil penelitian menunjukkan bahwa jika dikaji dari alasan pengajuan peninjauan kembali yang diatur dalam Undang-Undang Nomor 14 Tahun 1985 tentang
\end{abstract}

Mahkamah Agung, suatu putusan pengadilan dapat dijadikan alasan dalam permohonan peninjauan kembali, apabila ada pertentangan antara putusan yang satu dengan yang lain. Pertentangan itu harus antara putusan oleh peradilan yang sama atau sama tingkatan. Pengajuan putusan peninjauan kembali perkara pidana menjadi novum dalam peninjauan kembali perkara perdata atau sebaliknya, tidak dapat dibenarkan.

Kata kunci: peninjauan kembali, pidana, perdata, novum.

\section{ABSTRACT}

Law Number 15 of 2001 concerning Trademark stipulates that resolution of disputes or violations of brands can be taken through two alternative ways, namely filing a lawsuit to the Commercial Court (civil) and secondly filing a complaint with the investigator for a criminal settlement. These two solutions were taken at the same time by both parties, GG against GB. This case was then up to the extraordinary request for review. In the review of civil cases, GG filed a decision on a criminal case review as novum.Based on this, the problems outlined in 
this analysis is whether the decision of a criminal case review can be made novum in reviewing a civil case. The method used is a normative juridical research method or literature research method. As stipulated in Law Number 14 of 1985 concerning the Supreme Court, pertaining to the reasoning of filing an extraordinary request for case

\section{PENDAHULUAN}

\section{A. Latar Belakang}

Undang-Undang Nomor 15 Tahun 2001 tentang Merek memberikan dua alternatif penyelesaian sengketa terkait kepemilikan hak merek, yaitu dengan mengajukan gugatan ke pengadilanniaga(perdata) atau denganmelaporkan kepada penyidik untuk diselesaikan secara pidana jika terindikasi adanya tindak pidana. Adanya dua alternatif tersebut berpotensi menimbulkan dua jenis putusan yang bertentangan atau bertolak belakang. Di manabisa saja secara pidanatersangka dinyatakan bersalah melakukan tindak pidana di bidang merek, sedangkan secara perdata dianggap tidak melakukan pelanggaran merek. Bahkan bisa juga sebaliknya, pada peradilan pidana dinyatakan tidak melakukan tindak pidana di bidang merek, sedangkan secara perdata dinyatakan melakukan pelanggaran merek. Hal ini terjadi dalam sengketa merek antara PT GG (dengan merek GG) dengan AK pemilik PR JM (dengan merek GB).

Sengketa antara GG dengan GB bermula ketika GG menggugat secara perdata sekaligus memidanakan pemilik GB yaitu AK. Polemik atas kasus ini terjadi dikarenakan bertolak belakangnya putusan di peradilan pidana dan peradilan perdata. Untuk kasus perdatanya, awalnya GB dinyatakan menjiplak merek GG oleh Pengadilan Niaga pada Pengadilan Negeri Surabaya pada 12 September 2013. Di tingkat kasasi, GB dapat membalikkan keadaan. Di mana majelis hakim menyatakan review, the research result shows that a court decision can be used as an excuse to file a case review, provided that there is conflict between one decision and another. Filing a criminal case review decision as novum in civil case review or vice versa cannot be justified.

Keywords: case review, criminal, civil, novum.

bahwa GB tidak menjiplak GG. Sebab tidak ada persamaan bentuk, cara penempatan, dan persamaan bunyi yang dapat menimbulkan adanya kerancuan (news.detik.com).

Berbeda dengan kasus pidananya, AK awalnya dihukum sepuluh bulan oleh Pengadilan Negeri Kepanjen dan dikuatkan oleh Pengadilan Tinggi Surabaya. Bermodal putusan kasasi perdata, AK mengajukan peninjauan kembali. Akan tetapi di peninjauan kembali, majelis hakim peninjauan kembali menolak alasan yang diajukan oleh AK yang menyatakan bahwa Putusan Nomor 162K/Pdt.Sus-HKI/2014 baru ada setelah putusan pidana Pengadilan Negeri Kepanjen sehingga putusan tersebut bukan novum (news.detik.com).

Putusan peninjauan kembali perkara pidana AK ini kemudian diajukan oleh GG sebagai novum dalam peninjauan kembali kasus perdata. Dalam peninjauan kembali perkara perdata yang diajukan GG, majelis hakim peninjauan kembali menyatakan bahwa Putusan Nomor 104PK/Pid. Sus/2015 merupakan novum yang menentukan sehingga majelis hakim peninjauan kembali menyatakan bahwa merek GB menjiplak merek GG sehingga harus dicoret dari Daftar Umum Merek.

Kedua putusan peninjauan kembali perkara tersebut menimbulkan pertentangan satu sama lain, yaitu terkait pertimbangan majelis hakim dalam kedua perkara tersebut dalam menilai 
suatu putusan pengadilan dapat dikategorikan sebagai novum atau tidak. Dalam Putusan Nomor 104PK/Pid.Sus/2015, majelis hakim menyatakan bahwa putusan kasasi bukan merupakan sebuah novum karena putusan tersebut ada setelah pemeriksaan perkara tersebut dimulai. Sehingga menurut pertimbangan majelis hakim pada Putusan Nomor 104PK/Pid.Sus/2015 tidak dianggap sebagai novum.

Berbeda dengan Putusan Nomor 104PK/ Pid.Sus/2015, majelis hakim dalam Putusan Nomor 119PK/Pdt.Sus-HKI/2017 menyatakan bahwa Putusan Nomor 104PK/Pid.Sus/2015 dianggap sebagai bukti yang sangat menentukan sehingga dapat dianggap sebagai novum dan majelis hakim tidak mempertimbangkan kapan keluarnya putusan tersebut. Padahal jika dilihat terkait dengan keluarnya putusan yang diajukan sebagai novum,yaitu Putusan Nomor 104PK/Pid. Sus/2015 juga ada setelah pemeriksaan perkara perdata sengketa merek tersebut mulai berjalan.

Pertentangan antara putusan peninjauan kembali perkara perdata (Putusan Nomor 119PK/Pdt.Sus-HKI/2017) dengan putusan peninjauan kembali perkara pidana (Putusan Nomor 104PK/Pid.Sus/2015) dalam menilai novum yang diajukan menarik untuk dikaji lebih lanjut, terutama dikaitkan dengan alasan-alasan pengajuan peninjauan kembali yang diatur dalam Pasal 67 Undang-Undang Nomor 14 Tahun 1985 tentang Mahkamah Agung.

\section{B. Rumusan Masalah}

Berdasarkan uraian di atas, maka yang menjadi rumusan masalah adalah apakah putusan peninjauan kembali perkara pidana dapat dijadikan novum dalam peninjauan kembali perkara perdata?

\section{Tujuan dan Kegunaan}

Tulisan ini bertujuanuntuk mengetahui apakah putusan peninjauan kembali perkara pidana dapat dijadikan novum dalam peninjauan kembali perkara perdata. Lebih lanjut, tulisan ini diharapkan memiliki kegunaan sebagai berikut:

1. Secara teoritis, tulisan ini memiliki tujuan untuk memberikan pengembangan hukum terkait dengan alasan pengajuan peninjauan kembali di Mahkamah Agung;

2. Secara praktik, tulisan ini diharapkan memberikan masukan dalam melahirkan putusan-putusan yang tidak bertolak belakang dalam memahami alasan pengajuan peninjauan kembali.

\section{Tinjauan Pustaka}

\section{Pengertian dan Konsep Merek}

Merek adalah nama atau simbol yang diasosiasikan dengan produk atau jasa dan menimbulkan arti psikolog atau asosiasi. Merek juga berarti sebuah nama dan simbol yang bersifat membedakan (seperti sebuah logo, cap atau kemasan) untuk mengidentifikasi barang atau jasa dari seorang penjual atau kelompok penjual tertentu serta membedakannya dari barang atau jasa yang dihasilkan pesaing (Susanto \& Wijanarko, 2004: 5-6). Dalam arti klasik, merek dihubungkan dengan identifikasi sebuah produk dan pembedaannya dari produk-produk para pesaing, baik dalam bentuk pemakaian nama tertentu, logo spesifik, desain khusus, maupun tanda dan simbol visual lainnya.

Pengertian standar dari American Marketing Association yang dirumuskan pada tahun 1960 menyatakan bahwa merek adalah nama, istilah, simbol atau desain, maupun 
kombinasi di antaranya yang dimaksudkan untuk mengidentifikasikan barang atau jasa seorang penjual atau sekelompok penjual dan membedakannya dari barang atau jasa para pesaing (Casavera, 2009: 3).

Selain itu, beberapa ahli mengemukakan pendapat terkait dengan pengertian merek sebagai berikut:

1. Molengraaf berpendapat merek yaitu dengan mana dipribadikanlah sebuah barang tertentu untuk menunjukkan asal barang dan jaminan kualitasnya, sehingga bisa dibandingkan dengan barang-barang sejenis yang dibuat dan diperdagangkan oleh orang atau perusahaan lain (Gautama, 1987: 37).

2. Sutjipto berpendapat merek adalah suatu tanda, dengan mana suatu benda tertentu dipribadikan, sehingga dapat dibedakan dengan benda lain yang sejenis (Sutjipto, 1984: 82).

3. Keller sebagaimana yang dikutip oleh Tjiptono, merek adalah produk yang mampu memberikan dimensi tambahan yang secara unik membedakannya dari produkproduk lain yang dirancang untuk memuaskan kebutuhan serupa (Tjiptono, 2005: 19).

Selain pengertian yang dikemukakan para ahli tersebut, dalam Undang-Undang Nomor 15 Tahun 2001 tentang Merek juga disebutkan pengertian merek, yaitu tanda yang berupa gambar, nama, kata, huruf-huruf, angka-angka, susunan warna atau kombinasi dari unsurunsur tersebut yang memiliki daya pembeda dan digunakan dalam kegiatan perdagangan barang atau jasa. Pengertian merek sebagaimana disebutkan dalam Undang-Undang Nomor 15 Tahun 2001 tentang Merek mengalami perkembangan dengan diundangkannya UndangUndang Nomor 20 Tahun 2016 tentang Merek dan Indikasi Geografis, di mana disebutkan merek adalah tanda yang dapat ditampilkan secara grafis berupa gambar, logo, nama, kata, huruf, angka, susunan warna, dalam bentuk dua dimensi dan/atau tiga dimensi, suara, hologram atau kombinasi dari dua atau lebih unsur tersebut untuk membedakan barang dan/atau jasa yang diproduksi oleh orang atau badan hukum dalam kegiatan perdagangan barang dan/atau jasa.

Fungsi utama dari sebuah merek adalah agar konsumen dapat mencirikan suatu produk (baik itu barang maupun jasa) yang dimiliki oleh perusahaan sehingga dapat dibedakan dari produk perusahaan lain yang serupa atau yang mirip yang dimiliki oleh pesaingnya. Konsumen yang merasa puas dengan suatu produk tertentu akan membeli atau memakai kembali produk tersebut di masa yang akan datang.

Untukdapatmelakukanhal tersebutpemakai harus mampu membedakan dengan mudah antara produksi yang asli dengan produk-produk yang identik atau yang mirip. Untuk memungkinan satu perusahaan dapat membedakan dirinya dan produk yang dimiliki terhadap apa yang dimiliki oleh para pesaingnya, maka merek menjadi peran penting dalam pencitraan dan strategi pemasaran perusahaan, pemberian kontribusi terhadap citra, dan reputasi terhadap produk dari sebuah perusahaan di mata konsumen.

Citra dan reputasi perusahaan untuk menciptakan kepercayaan merupakan dasar untuk mendapatkan pembeli yang setia dan meningkatkan nama baik perusahaan. Konsumen sering memakai faktor emosional pada merek tertentu, berdasarkan serentetan kualitas yang diinginkan atau fitur-fitur yang terwujud dalam produk-produk yang dimiliki merek tersebut. Merek juga dapat menjadi nilai tambah bagi perusahaan untuk berinvestasi dalam memelihara dan meningkatkan kualitas produk yang mereka 
miliki guna menjamin bahwa merek produk yang mereka miliki memiliki reputasi yang baik (WIPO, 2008: 4).

Selain itu, merek juga mempunyai beberapa fungsi yaitu:

1. Memberikan jaminan kepada konsumen untuk membedakan satu produk dengan produk lainnya;

2. Membuat perusahaan dapat membedakan produk-produk yang mereka miliki;

3. Merupakan alat pemasaran dan dasar untuk membangun citra dan reputasi;

4. Dapat dilisensikan/waralaba sehingga menjadi sumber penghasilan langsung berupa royalti;

5. Merupakan bagian penting dalam persetujuan waralaba;

6. Dapat menjadi aset bisnis yang sangat berharga;

7. Mendorong perusahaan untuk berinvestasi dalam memelihara/ menjaga atau meningkatkan kulitas produk;

8. Merupakan hal yang sangat bermanfaat untuk menambah pendapatan (WIPO, 2008: 4).

Menurut Keller sebagaimana yang dikutip oleh Tjiptono, merek bermanfaat bagi produsen dan konsumen. Bagi produsen, merek berperan penting sebagai:

1. Sarana identifikasi untuk memudahkan proses penanganan atau pelacakan produk bagi perusahaan, terutama dalam pengorganisasian sediaan dan pencatatan akuntansi.

2. Bentuk proteksi hukum terhadap fitur atau aspek produk yang unik.

3. Signal tingkat kualitas bagi para pelanggan yang puas, sehingga mereka bisa dengan mudah memilih dan membelinya lagi di lain waktu.

4. Sarana menciptakan asosiasi dan makna unik yang membedakan produk dari para pesaing.

5. Sumber keunggulan kompetitif, terutama melalui perlindungan hukum, loyalitas pelanggan, dan citra unik yang terbentuk dalam benak konsumen.

6. Sumber financial return, terutama menyangkut pendapatan masa datang. Sedangkan manfaat merek bagi konsumen yaitu sebagai identifikasi sumber produk, penetapan tanggung jawab pada pemanufaktur atau distributor tertentu, pengurang resiko, penekanan biaya pencarian (search cost) internal dan eksternal, janji atau ikatan khusus dengan produsen, alat simbolis yang memproyeksikan citra diri dan signal kualitas (Tjiptono, 2005: 21).

\section{Pendaftaran Merek}

Pendaftaran atas merek merupakan suatu keharusan bagi pemilik merek, akan tetapi hak atas merek hanya akan diberikan oleh Direktorat Merek jika permintaan pendaftaran merek oleh pemohon merek dilakukan dengan iktikad baik. Unsur iktikad baik dalam suatu permintaan pendaftaran merek merupakan unsur yang penting, seperti tercantum dalam Pasal 4 UndangUndang Nomor 15 Tahun 2001 tentang Merek yang menyebutkan bahwa merek tidak dapat didaftar atas dasar permohonan yang diajukan oleh pemohon yang beriktikad tidak baik.

Pemohon yang beriktikad baik adalah pemohon yang mendaftarkan mereknya secara jujur dan layak tanpa ada niat apapun untuk membonceng, meniru atau menjiplak ketenaran merek pihak lain demi kepentingan usahanya yang berakibat kerugian pada pihak lain itu atau menimbulkan kondisi persaingan curang, mengecoh atau menyesatkan konsumen (Mardianto, 2010: 44).

Berdasarkan Undang-Undang Nomor 15 Tahun 2001 tentang Merek, pendaftaran merek menggunakan sistem konstitutif. Pada prinsip konstitutif ini disyaratkan adanya pendaftaran 
merek bagi seseorang atau badan hukum untuk memperoleh perlindungan hukum dan pengakuan hak atas merek (Djumhana \& Djubaedillah, 2003: 187). Tanpa pendaftaran, negara tidak akan memberikan hak atas merek kepada pemilik merek. Hal ini berarti tanpa mendaftarkan merek, seseorang tidak akan diberikan perlindungan hukum oleh negara apabila mereknya ditiru oleh orang lain. Pada sistem konstitutifini perlindungan hukumnya didasarkan atas pendaftar pertama yang beriktikad baik (hal ini juga seperti yang tercantum dalam Pasal 4 Undang-Undang Nomor 15 Tahun 2001 yang menyatakan bahwa merek tidak dapat didaftar oleh pemohon yang tidak beriktikad baik (Usman, 2003: 326)).

Pasal 1 butir 5 Undang-Undang Nomor 15 Tahun 2001 menyebutkan bahwa permohonan merupakan permintaan pendaftaran yang diajukan secara tertulis kepada Direktorat Merek, sehingga dimungkinkan permohonan pendaftaran merek dapat berlangsung dengan tertib. Pemeriksaan merek tidak hanya dilakukan berdasarkan kelengkapan persyaratan formal saja, tetapi juga dilakukan pemeriksaan substantif. Pemeriksaan subtantif atas permohonan pendaftaran merek ini dimaksudkan untuk menentukan dapat atau tidaknya merek yang dimohonkan didaftarkan dalam Daftar Umum Merek.

Pemeriksaan substantif dilakukan dalam jangka waktu paling lama sembilan bulan. Apabila dari hasil pemeriksaan subtantif ternyata permohonan tersebut tidak dapat diterima atau ditolak, maka atas persetujuan Direktorat Merek, hal tersebut diberitahukan secara tertulis pada pemohon atau kuasanya dengan menyebutkan alasannya. Pasal 4, 5, dan 6 Undang-Undang Nomor 15 Tahun 2001 tentang Merek menyatakan bahwa merek tidak dapat didaftarkan atas iktikad tidak baik, merek juga tidak dapat didaftar apabila merek tersebut mengandung salah satu unsur yang bertentangan dengan peraturan perundangundangan yang berlaku, moralitas agama, kesusilaan atau ketertiban umum, tidak memiliki daya pembeda, telah menjadi milik umum, dan merupakan keterangan atau berkaitan dengan barang atau jasa yang dimohonkan pendaftaran.

Permohonan merek juga harus ditolak apabila merek tersebut mempunyai persamaan pada pokoknya atau keseluruhannya dengan merek pihak lain yang sudah terdaftar terlebih dahulu untuk barang atau jasa yang sejenis, mempunyai persamaan pada pokoknya atau keseluruhannya dengan indikasi geografis yang sudah dikenal (Ramli, 2004: 11).

Berdasarkan ketentuan persyaratan merek agar dapat didaftarkan, sesuatu dapat dikategorikan dan diakui sebagai merek, apabila mempunyai fungsi pembeda, merupakan tanda pada barang atau jasa (unsur-unsur gambar, nama, kata, huruf, angka, susunan warna atau kombinasi dari unsur-unsur tersebut), tidak memenuhi unsur-unsur yang bertentangan dengan kesusilaan dan ketertiban umum, bukan menjadi milik umum, tidak merupakan keterangan atau berkaitan dengan barang atau jasa yang dimintakan pendaftaran.

Selain pemeriksaan substantif, harus pula ditempuh mekanisme pengumuman dalam waktu tiga bulan dengan menempatkan pada papan pengumuman yang khusus dan dapat dengan mudah dilihat oleh masyarakat dalam Berita Resmi Merek yang diterbitkan secara berkala oleh Direktorat Merek. Hal ini dilakukan untuk memungkinkan pihak-pihak yang dirugikan mengajukan bantahan terhadap pendaftaran merek dan dapat mencegah pendaftaran merek yang dilakukan oleh orang yang tidak beriktikad 
baik. Apabila masa pengumuman berakhir dan tidak ada sanggahan atau keberatan dari pihak lain, Direktorat Merek mendaftarkan merek tersebut dalam Daftar Umum Merek serta dilanjutkan dengan pemberian sertifikat merek. Sertifikat merek merupakan alat bukti bahwa merek telah terdaftar dan juga sebagai bukti kepemilikan.

Terkait dengan pendaftaran merek mengalami perubahan dengan diundangkannya Undang-Undang Nomor 20 Tahun 2016 tentang Merek dan Indikasi Geografis. Perubahan yang signifikan terjadi pada proses pendaftaran merek, di mana berdasarkan Undang-Undang Nomor 15 Tahun 2001 tentang Merek, tahapan-tahapan yang ditempuh yaitu pemeriksaan formalitas, pemeriksaan substantif, dan dilanjutkan dengan pengumuman. Tahapan-tahapan tersebut berubah pada Undang-Undang Nomor 20 Tahun 2016 tentang Merek dan Indikasi Geografis, di mana tahapan-tahapan pendaftaran menjadi pemeriksaan formalitas, pengumuman, dan pemeriksaan substantif.

\section{Penyebab Sengketa Merek}

Pelanggaran merek seringkali dilakukan karena terkait dengan fungsi merek sebagai identitas suatu produk atau jasa yang telah mempunyaireputasi danjuga terkait dengan fungsi merek sebagai jaminan terhadap kualitas barang (Dianggoro, 1997: 34). Hal ini dikarenakan dalam merek melekat keuntungan ekonomis, terutama merek terkenal. Fungsi merek yaitu sebagai identitas dari suatu produk atas suatu perusahaan tertentu, sehingga konsumen dapat membedakan antara produk yang satu dan lainnya untuk jenis produk yang sama (Sembiring, 2002: 55).

Munculnya sengketa merek khususnya antara pemilik merek terkenal (asing) dengan pengusaha lokal pada saat itu secara tidak langsung terjadi karena penerapan sistem ekonomi terbuka pada saat itu dan kesempatan menikmati produkproduk bermerek asing yang kebetulan belum didaftar oleh pemiliknya (Maulana, 1999: 16-17). Selain itu, pada umumnya sengketa merek timbul disebabkan hal-hal yang sekaligus menjadi indikasi dan peluang timbulnya pemboncengan reputasi sebagai berikut:

1. Merek-merek yang diterima pendaftarannya mempunyai persamaan pada pokoknya atau keseluruhannya antara merek yang satu dengan merek yang lainnya atau merek yang didaftar tersebut sama atau menyerupai merek terkenal (baik yang sudah terdaftar maupun belum terdaftar).

2. Dalam praktik banyak pemakaian merek menyimpang dari apa yang telah didaftarkan baik pada etiket mereknya maupun dalam peruntukan jenis barang atau jasa yang didaftar. Dan hal yang tidak sesuai atau menyimpang tersebut justru yang menimbulkan ada persamaan atau menyerupai merek orang lain (Maulana, 1999: 102).

\section{Penyelesaian Pelanggaran/Sengketa Merek}

Merek sebagai identitas dari suatu merek akan merujuk pada kualitas (mutu) dan harga terhadap suatu produk barang dan/atau jasa yang telah dibentuk oleh pemiliknya (Saidin, 2006: 330). Sesuai dengan Pasal 1 angka 1 UndangUndang Nomor 15 Tahun 2001 tentang Merek disebutkan bahwa merek tanda yang berupa gambar, nama, kata, huruf-huruf, angka-angka, susunan warna atau kombinasi dari unsur-unsur tersebut yang memiliki daya pembeda dan digunakan dalam kegiatan perdagangan barang atau jasa. 
Dari pengertian merek yang diatur dalam Undang-Undang Nomor 15 Tahun 2001 tentang Merek dapat diketahui bahwa fungsi dari suatu merek adalah sebagai pembeda dengan produk dan/atau jasa yang sejenis. Menurut Dermawan, fungsi merek itu ada tiga yaitu:

1. Fungsi indikator sumber, artinya merek berfungsi untuk menunjukkan bahwa suatu produk bersumber secara sah pada suatu unit usaha dan karenanya juga berfungsi untuk memberikan indikasi bahwa produk itu dibuat secara profesional;

2. Fungsi indikator kualitas, artinya merek berfungsi sebagai jaminan kualitas khususnya dalam kaitan dengan produk-produk bergengsi; dan

3. Fungsi sugestif, artinya merek memberikan kesan akan menjadi kolektor produk tersebut (Saidin, 2006: 359).

Berdasarkan fungsi inilah maka diperlukan perlindungan hukum terhadap hak merek, ada tiga bentuk perlindungannya yaitu:

1. Untuk menjamin adanya kepastian hukum bagi para penemu merek, pemilik merek atau pemegang hak merek;

2. Untuk mencegah terjadinya pelanggaran dan kejahatan atas hak merek sehingga keadilan hukum dapat diberikan kepada pihak yang berhak; dan

3. Untuk memberi manfaat kepada masyarakat agar masyarakat lebih terdorong untuk membuat dan mengurus pendaftaran merek usaha mereka (Hariyani, 2010: 89).

Dalam rangka memberikan perlindungan hukum kepada pemilik merek, UndangUndang Nomor 15 Tahun 2001 tentang Merek memberikan dua model penyelesaian jika kemudian terhadap merek yang sudah terdaftar ditemukan pelanggaran oleh pihak lain. Penyelesaian yang pertama adalah melalui jalur sengketa perdata, dan yang kedua melalui jalur sengketa pidana. Bahkan dapat ditempuh kedua jalur tersebut secara bersama-sama.

Berdasarkan ketentuan Pasal 76 UndangUndang Nomor 15 Tahun 2001 tentang Merek disebutkan bahwa pemilik merek terdaftar dapat mengajukan gugatan melalui pengadilan niaga terhadap pihak lain yang secara tanpa hak menggunakan merek yang mempunyai persamaan pada pokoknya atau keseluruhannya untuk barang atau jasa yang sejenis. Gugatan dapat berupa ganti rugi, dan/atau penghentian semua perbuatan yang berkaitan dengan penggunaan merek tersebut. Gugatan tersebut diajukan kepada pengadilan niaga.

Untuk sengketa pidana, yang melibatkan negara melawan pelaku tindak pidana, berdasarkan aturan normatif, wajib diselesaikan melalui jalur lembaga peradilan umum. Dalam sistem hukum di Indonesia, semua pelanggaran di bidang merek, dikategorikan sebagai suatu tindak pidana (Sulistiyono, 2004: 49-68).

\section{Alasan Pengajuan Peninjauan Kembali}

Mahkamah Agung selaku puncak peradilan memiliki fungsi sebagai kurator atas kinerja dan hasil kinerja judex facti, pengemban amanah menjaga kesatuan penerapan hukum dan konsistensi putusan, dan membina pengadilan bawahan. Dalam rangka melaksanakan fungsi tersebut, dapat dilakukan melalui dua cara, yaitu:

1. Pemeriksaan pada tingkat kasasi terhadap putusan judex facti yang belum berkekuatan hukum tetap. Terhadap putusan judex facti yang sudah berkekuatan hukum tetap tidak dapat dimohonkan kasasi;

2. Pemeriksaan pada tingkat peninjauan kembali terhadap putusan judex facti maupun judex juris yang telah 
berkekuatan hukum tetap sebagai upaya hukum luar biasa (Arto, 2018: 131).

Peninjauan kembali merupakan upaya hukum luar biasa yang diberikan kepada seseorang untuk dalam suatu hal tertentu melawan keputusan hakim (Sutantio \& Winata, 1983: 121). Menurut Muhammad, walaupun putusan hakim itu telah selesai dilaksanakan, masih ada kemungkinan untuk melakukan permohonan kasasi, apabila ternyata ada alasan untuk itu dan dirasakan tidak adil jika terus berpegang pada putusan semacam itu. Peninjauan kembali itu bukanlah menghilangkan kepastian hukum dari putusan hakim, melainkan justru untuk mempertahankan keadilan itu sendiri dan memberikan kepastian hukum pada perbuatan yang adil. Peninjauan kembali bersifat insidental saja, terus-menerus, tidak selalu ditemukan mungkin dalam seribu perkara yang diputus hakim yang telah memperoleh keputusan hukum tetap, muncullah satu perkara yang ditemukan oleh yang berkepentingan dengan alasannya bahwa putusan itu perlu dilakukan peninjauan kembali (Muhammad, 1986: 102).

Penempatan peninjauan kembali sebagai salah satu upaya hukum dalam sistem hukum acara peradilan dimaksudkan sebagai upaya untuk memberikan perlindungan atas hak asasi manusia, tanpa mengorbankan asas kepastian hukum, yang merupakan sendi dasar dari suatu negara hukum (Chazawi, 2011: 109).

Sesuai dengan ketentuan Pasal 67 Undang-Undang Nomor 14 Tahun 1985 tentang Mahkamah Agung, alasan peninjauan kembali bersifat limitatif. Artinya, alasan permohonan peninjauan kembali hanya terbatas atas alasan yang disebut secara enumeratif satu persatu dalam pasal tersebut. Tidak boleh ditambah di luar yang disebut pada pasal itu. Alasan yang demikian dianggap tidak memenuhi ketentuan Pasal 67 Undang-Undang Nomor 14 Tahun 1985 tentang Mahkamah Agung (Harahap, 2008: 449450).

Adapun alasan-alasan pengajuan peninjauan kembali sebagaimana diatur dalam Pasal 67 Undang-Undang Nomor 14 Tahun 1985 tentang Mahkamah Agung, yaitu:

a. Putusan didasarkan pada suatu kebohongan atau tipu muslihat dari pihak lawan.

Alasan yang pertama ini, apabila putusan yang bersangkutan memenuhi kriteria berikut: 1) putusan didasarkan pada suatu kebohongan atau tipu muslihat pihak lawan, dan kebohongan atau tipu muslihat itu diketahui setelah perkaranya putus; dan 2) putusan didasarkan pada bukti-bukti yang kemudian oleh hakim pidana dinyatakan palsu.

Dalam praktik peradilan, alasan peninjauan kembali kebohongan atau tipu muslihat, jarang ditemukan. Sulit mewujudkan secara konkret dan objektif adanya kebohongan atau tipu muslihat dalam suatu putusan, kecuali apabila telah ada putusan pengadilan pidana yang berkekuatan hukum tetap menyatakan alat bukti yang digunakan pihak lawan adalah palsu setelah putusan perdata berkekuatan hukum tetap, barulah alasan ini efektif dan memiliki daya untuk mengabulkan peninjauan kembali. Sebaliknya, alasan kebohongan atau tipu muslihat, sangat sulit mengkonstruksi wujudnya secara konkret dan objektif. Oleh karena itu, agar alasan kebohongan atau tipu muslihat benar-benar efektif, pemohon harus mampu menunjukkan dengan jelas dan rinci dimana letak kebohongan atau tipu muslihat yang dilakukan pihak lawan dalam putusan tersebut.

b. Ditemukan surat-surat bukti yang bersifat menentukan. 
Alasan kedua peninjauan kembali sebagaimana disebutkan Pasal 67 huruf $b$ Undang-Undang Nomor 14 Tahun 1985 tentang Mahkamah Agung yaitu apabila setelah perkara diputus, ditemukan surat-surat bukti yang bersifat menentukan yang pada waktu perkara diperiksa tidak dapat ditemukan.

Menurut ketentuan ini, setelah perkara diputus, yakni setelah putusan itu berkekuatan hukum tetap: 1) ditemukan surat-surat bukti yang bersifat menentukan; dan 2) surat-surat bukti itu telah ada sebelum gugatan atau sebelum perkara diajukan ke pengadilan, namun selama proses persidangan berlangsung mulai dari tingkat pertama, banding, dan kasasi, tidak dapat ditemukan.

Berkenaaan dengan alasan ini, dapat dijelaskan hal-hal sebagai berikut:

1) Penerapan alasan ini terbatas pada bentuk alat bukti surat;

2) Surat bukti yang memenuhi syarat alasan peninjauan kembali, harus bersifat menentukan;

3) Hari dan tanggal surat bukti itu ditemukan, harus dinyatakan di bawah sumpah atau disahkan pejabat yang berwenang; dan

4) Surat bukti itu telah ada sebelum proses pemeriksaan perkara.

c. Putusan mengabulkan sesuatu hal yang tidak dituntut atau lebih daripada yang dituntut.

Alasan ketiga pengajuan peninjauan kembali adalah apabila telah dikabulkan sesuatu hal, yang tidak dituntut atau lebih daripada yang dituntut. Alasan ini dapat diklasifikasi sebagai berikut: 1) putusan mengabulkan sesuatu hal yang tidak dituntut; 2) putusan melebihi dari apa yang dituntut.

d. Terdapat suatu bagian dari tuntutan yang belum diputus tanpa dipertimbangkan sebabnya.

Alasan permohonan peninjauan kembali yang keempat adalah apabila mengenai satu bagian dari tuntutan belum diputus tanpa dipertimbangkan sebab-sebabnya.

Dalam praktik, kasus yang seperti ini jarang terjadi. Jika terjadi kelalaian yang seperti itu oleh pengadilan tingkat pertama, pada umumnya akan dikoreksi dan diluruskan oleh pengadilan tingkat banding. Kalau tingkat pertama dan/atau tingkat banding lalai memutus seluruh bagian perkara, akan dikoreksi dan diluruskan Mahkamah Agung pada tingkat kasasi. Pada umumnya, melalui fungsi dan kewenangan koreksi yang dimiliki tingkat banding dan kasasi berdasarkan mekanisme instansional, jarang dijumpai putusan berkekuatan hukum tetap yang lalai memutus semua bagian tuntutan.

e. Terdapat putusan yang bertentangan antara yang satu dengan yang lain.

Alasan peninjauan kembali yang diatur dalam Pasal 67 huruf 3 Undang-Undang Nomor 14 Tahun 1985 tentang Mahkamah Agung disebutkan apabila antara pihakpihak yang sama mengenai suatu soal yang sama, atas dasar yang sama oleh pengadilan yang sama atau sama tingkatannya telah diberikan putusan yang bertentangan dengan satu dengan yang lain.

Supaya alasan ini memiliki validitas, harus dipenuhi syarat sebagai berikut: 1) terdapat dua atau lebih putusan yang saling bertentangan; 2) pihak yang terlibat dalam putusan yang saling bertentangan tersebut adalah sama; 3) mengenai soal atau dasar yang sama; 4) oleh pengadilan yang sama atau sama tingkatannya; 5) putusan yang terakhir dan bertentangan itu telah berkekuatan hukum tetap.

f. Terdapat suatu kekhilafan hakim atau suatu kekeliruan yang nyata.

Alasan keenam, apabila dalam suatu putusan terdapat suatu kekhilafan. Jadi, putusan yang bersangkutan mengandung kekhilafan atau 
kekeliruan nyata. Dalam praktik, alasan peninjauan kembali yang paling sering dan paling besar konsekuensinya adalah kekhilafan atau kekeliruan nyata. Sebab alasan ini dianggap sangat luas jangkauannya (Harahap, 2008: 450472).

\section{METODE}

Metode yang digunakan dalam tulisan ini adalah metode penelitian yuridis normatif atau penelitian hukum kepustakaan yaitu metode atau cara yang digunakan di dalam penelitian hukum yang dilakukan dengan cara meneliti bahan pustaka yang ada (Soekanto \& Mamudji, 2009: 13-14).

Adapun sifat penelitian yang dipergunakan dalam tulisan ini adalah preskriptif, berpegang pada karakteristik ilmu hukum sebagai ilmu terapan, preskripsi yang diberikan di dalam kegiatan penelitian hukum harus dapat dan mungkin untuk diterapkan. Oleh karena itu yang dihasilkan oleh penelitian hukum, sekalipun bukan asas hukum yang baru atau teori baru, paling tidak argumentasi baru (Marzuki, 2011: 251).

\section{HASIL DAN PEMBAHASAN}

\section{A. Alasan Peninjauan Kembali dalam Putusan Nomor 119PK/Pdt.Sus- HKI/2017}

Pada Putusan Nomor 119PK/Pdt.SusHKI/2017, GG mengajukan tiga alasan pengajuan peninjauan kembali, yaitu:

1. Adanya novum. Adapun novum yang diajukan adalah Putusan Nomor 104PK/ PID.SUS/2015 tanggal 10 November 2015, yang baru diberitahukan kepadapihak-pihak pada tanggal 20 September 2016 kepada Kejaksaan Negeri Kepanjen dan tanggal 21 September 2016 kepada terdakwa; Surat Perintah Pelaksanaan Putusan Pengadilan Nomor 739/O.5.43/Euh.3/03/2016 Kepala Kejaksaan Negeri Kepanjen tanggal 29 Maret 2016; dan Berita Acara Pelaksanaan Putusan Pengadilan Kejaksaan Negeri Kepanjen tanggal 11 April 2016. Selain itu disebutkan bahwa bukti tersebut ditemukan dan diperoleh pada tanggal 13 Oktober 2016, dan bukti-bukti ini penting dan menentukan yang apabila diketahui dan dipertimbangkan pada tahap persidangan akan menghasilkan putusan yang berbeda.

2. Putusan yang saling bertentangan satu dengan yang lain. Adapun putusan yang saling bertentangan adalah Putusan Nomor 162K/Pdt.Sus-HKI/2014 dan Putusan Nomor 104PK/Pid.Sus/2015. Dalam Putusan Nomor 162K/Pdt.Sus-HKI, pertimbangan hakim menyatakan bahwa adanya iktikad baik dari termohon; dan tidak adanya persamaan pokok merek dan gambar GB dengan merek dan gambar GG. Sedangkan dalam Putusan Nomor 104PK/Pid.Sus/2015, pertimbangan hakim menyatakan bahwa termohon telah terbukti secara sah dan meyakinkan menurut hukum bersalah melakukan tindak pidana "dengan sengaja dan tanpa hak menggunakan merek yang sama pada pokoknya dengan merek terdaftar milik pemohon; dan adanya persamaan pada pokoknya antara merek GG dengan merek GB.

3. Adanya kekhilafan majelis hakim atau kekeliruan nyata. Kekhilafan atau kekeliruan ini dilihat dari beberapa hal, yaitu: majelis hakim kasasi mengabaikan 
merek GG milik pemohon sebagai merek terkenal (fakta notoir). Padahal merek GG selain dikenal dan diketahui masyarakat luas selama ini, juga reputasinya telah diperoleh berkat promosi yang gencar dan besarbesaran, yaitu melalui media iklan, begitu pula telah terdaftar di beberapa negara di dunia sejak tahun 1989, antara lain Jepang, Singapura, Argentina, Malaysia, Brasil, Brunei Darussalam, Chili, Korea Selatan, Paraguay, Saudi Arabia, Filipina, Qatar, Taiwan, dan beberapa negara di benua Eropa.

Dari alasan-alasan yang disampaikan dalam Putusan Nomor 119PK/Pdt.Sus-HKI/2017 yaitu adanya novum yang menentukan, yaitu Putusan Nomor 104PK/Pid.Sus/2015, adanya pertentangan antara putusan dengan yang lain, dan adanya kekhilafan atau kelalaian hakim. Dari ketiga alasan yang diajukan tersebut, hanya dua alasan yang diperiksa oleh majelis hakim, yaitu adanya novum dan adanya kekhilafan atau kelalaian hakim.

Majelis hakim dalam perkara ini menerima bukti baru atau novum berupa putusan pidana atas nama AK beserta perintah pelaksanaan dan berita acara pelaksanaan putusan, dan Mahkamah Agung pada tingkat peninjauan kembali berpendapat bahwa bukti-bukti tersebut bersifat menentukan dan bersesuaian dengan pendapat judex facti bahwa merek GB dan variannya memiliki persamaan pada pokoknya dengan merek GG yang telah terdaftar dan terkenal.

\section{B. Alasan Peninjauan Kembali dalam Putusan Nomor 104PK/Pid.Sus/2015}

Dalam Putusan Nomor 104PK/Pid. Sus/2015, AK (pemilik PR JM) sebagai pemilik merek GB mengajukan tiga alasan peninjauan kembali, yaitu:

1. Terdapat keadaan baru berupa sertifikat merek asli pemohon Nomor 370277 dan Nomor 380919, yang mana bukti tersebut menimbulkan dugaan bahwa seandainya keadaan tersebut diketahui pada waktu sidang masih berlangsung, hasilnya akan berupa putusan bebas atau putusan lepas dari segala tuntutan hukum atau tuntutan penuntut hukum tidak dapat diterima atau terhadap perkara itu diterapkan ketentuan pidana yang lebih ringan;

2. Terdapat keadaan baru berupa Putusan Nomor 162K/Pdt.Sus-HKI/2014, di mana pada pokoknya putusan tersebut membatalkan Putusan Nomor 04/HKIMEREK/2013/PN.NIAGA.SBY， dengan pertimbangan bahwa karena judex facti telah keliru dalam menerapkan hukum yaitu terkait dengan pertimbangan tentang adanya iktikad tidak baik; dan tentang adanya persamaan pada pokoknya, dimana pertimbangan judex facti tentang adanya persamaan pada pokoknya sangat tidak tepat karena komposisi kata dan gambar yang digunakan tidak ada persamaan bentuk, cara penempatan atau persamaan bunyi, yang diklaim dapat menimbulkan adanya kerancuan bagi masyarakat;

3. Adanya suatu kekhilafan hakim atau kekeliruan yang nyata. Kekhilafan hakim atau kekeliruan ini dapat dilihat di mana putusan judex facti telah menetapkan keadaan hukum baru, yaitu memutus secara sepihak PT GG Tbk adalah pemilik merek terdaftar yang sah. 
Dari tiga alasan yang diajukan, majelis hakim dalam perkara ini mempertimbangkan sebagai berikut:

1. Bahwa tidak ada kekhilafan atau kekeliruan yang nyata dalam putusan judex facti Pengadilan Negeri Kepanjen jo. Pengadilan Tinggi Surabaya karena hal-hal yang relevan secara yuridis telah dipertimbangkan secara benar;

2. Bahwa keadaan baru berupa sertifikat merek asli pemohon Nomor 370277 dan Nomor 380919 tidak dapat dipertimbangkan karena bukti tersebut sudah diajukan di penyidikan maupun dalam persidangan, sehingga bukti sertifikat tersebut bukan novum;

3. Bahwa Putusan Nomor 162K/Pdt.SusHKI/2014 baru ada setelah adanya Putusan Nomor 645/Pid.Sus/2011/PN.Kpj dan Putusan Nomor 297/Pid/2012/PT.Sby, dengan demikian Putusan Mahkamah Agung tersebut bukan novum.

Berdasarkan pertimbangan majelis hakim dalam putusan ini, jelas bahwa majelis hakim tidak mengakui Putusan Nomor 162K/Pdt.SusHKI/2014 sebagai novum dikarenakan putusan ini keluar jauh setelah perkaranya diperiksa di pengadilan. Sehingga tidak memenuhi persyaratan sebagai novum seperti yang diatur dalam Pasal 67 huruf b Undang-Undang Nomor 14 Tahun 1985 tentang Mahkamah Agung. Dalam hal ini, majelis hakim sudah tepat menerapkan pasal tersebut terkait dengan alasan pengajuan peninjauan kembali.

\section{Penafsiran Novum dalam Putusan Nomor 119PK/Pdt-Sus-HKI/2017 dan Nomor 104PK/Pid.Sus/2015}

Berdasarkan ketentuan Pasal 67 huruf b Undang-Undang Nomor 14 Tahun 1985 tentang Mahkamah Agung, suatu novum harus memenuhi persyaratan bahwa novum tersebut harus bersifat menentukan, dan novum tersebut ada sebelum perkara mulai diperiksa, dan novum tersebut tidak ditemukan ketika proses pemeriksaan berlangsung. Terkait dengan adanya novum dalam Putusan Nomor 119PK/Pdt.Sus-HKI/2017 yaitu Putusan Nomor 104PK/Pid.Sus/2015, juga harus dikaji berdasarkan ketentuan Pasal 67 huruf b Undang-Undang Nomor 14 Tahun 1985 yang menyatakan bahwa apabila setelah perkara diputus, ditemukan surat-surat bukti yang bersifat menentukan yang pada waktu perkara diperiksa tidak dapat ditemukan.

Berdasarkan ketentuan ini dan pendapat dari Harahap (2008: 458), maka Putusan Nomor 104PK/Pid.Sus/2015 sebagai novum harus memenuhi syarat, salah satunya adalah surat bukti itu telah ada sebelum proses pemeriksaan perkara. Artinya bahwa surat yang dapat dijadikan novum, harus surat bukti yang telah ada keadaannya sebelum gugatan dan proses pemeriksaan perkara dimulai, namun selama proses pemeriksaan perkara berlangsung sampai putusan perkara itu berkekuatan hukum tetap, tidak ditemukan, dan baru ditemukan setelah putusan perkara itu berkekuatan hukum tetap.

Berdasarkan syarat tersebut, pengajuan putusan peninjauan kembali sebagai novum tidak terpenuhi. Karena putusan tersebut ada setelah bahkan jauh setelah perkara tersebut dimulai, dan belum ada sebelum perkara tersebut mulai diperiksa. Pemahaman yang tepat berdasarkan ketentuan ini justru ada pada Putusan Nomor 104PK/Pid.Sus/2014, di mana pemohon peninjauan kembali mengajukan Putusan Nomor 162K/Pdt.Sus-HKI/2014 sebagai novum yang 
menentukan ditolak oleh majelis hakim dengan alasan bahwa putusan tersebut ada setelah dimulainya perkara, sehingga tidak memenuhi syarat yang ditentukan dalam Pasal 67 huruf $b$ Undang-Undang Nomor 14 Tahun 1985 tentang Mahkamah Agung.

Alasan yang diajukan selanjutnya adalah adanya pertentangan antara satu putusan dengan putusan yang lain yang diputus atas dasar yang sama, pihak yang sama, dan oleh pengadilan yang sama ataupun sama tingkatan, sebagaimana diatur dalam Pasal 67 huruf e Undang-Undang Nomor 14 Tahun 1985 tentang Mahkamah Agung. Adapun putusan yang dianggap bertentangan satu sama lain adalah antara Putusan Nomor 162K/Pdt.Sus-HKI/2014 dengan Putusan Nomor 104PK/Pid.Sus/2015.

Alasan ini memang tidak dipertimbangkan oleh majelis hakim, akan tetapi sekalipun dipertimbangkan oleh majelis hakim, maka alasan ini tidak memenuhi syarat Pasal 67 huruf e Undang-Undang Nomor 14 Tahun 1985 yang mensyaratkan putusan dari pengadilan yang sama atau yang sama tingkatan. Sedangkan yang diajukan adalah putusan yang bertentangan dan sama pengadilan tetapi berbeda tingkatan antara putusan kasasi dengan putusan peninjauan kembali.

Putusan Nomor 119PK/Pdt.Sus-HKI/2017 yang mengajukan Putusan Nomor 104PK/Pid. Sus/2015 sebagai novum seyogianya juga harus diputuskan sama dengan Putusan Nomor 104PK/ Pid.Sus/2015 yang mengajukan Putusan Nomor 162K/Pdt.Sus-HKI/2014. Baik Putusan Nomor 104PK/Pid.Sus/2015 maupun Putusan Nomor 162K/Pdt.Sus-HKI/2014, sama-sama muncul jauh setelah perkara yang diputuskan tersebut dimulai pemeriksaannya. Oleh karena itu, dalam
Putusan Nomor 119PK/Pdt.Sus-HKI/2017, majelis hakim tidak mempertimbangkan tanggal dikeluarkannya Putusan Nomor 104PK/Pid. Sus/2015 yang diajukan sebagai novum.

Hal ini tentunya bertentangan dengan Pasal 67 huruf b Undang-Undang Nomor 14 Tahun 1985 tentang Mahkamah Agung yang menyebutkan bahwa salah satu alasan diterimanya peninjauan kembali adalah apabila setelah perkara diputus, ditemukan surat-surat bukti yang bersifat menentukan yang pada waktu perkara diperiksa tidak dapat ditemukan.Penerapan Pasal 67 huruf b Undang-Undang Nomor 14 Tahun 1985 tentang Mahkamah Agung tidak diterapkan secara benar, karena majelis hakim tidak mempertimbangkan waktu ditemukannya bukti tersebut, dan hanya mempertimbangkan bahwa bukti tersebut bersifat menentukan atau tidak.

\section{KESIMPULAN}

Berdasarkan uraian di atas dan berdasarkan analisis terhadap Putusan Nomor 119PK/Pdt. Sus-HKI/2017 dan Putusan Nomor 104PK/Pid. Sus/2014, dapat disimpulkan bahwa: terdapat perbedaan penafsiran majelis hakim dalam Putusan Nomor 119PK/Pdt.Sus-HKI/2017 dan Putusan Nomor 104PK/Pid.Sus/2014 dalam menilai putusan pengadilan yang dijadikan sebagai novum dalam perkara peninjauan kembali.

Suatu surat atau bukti dapat diajukan sebagai novumapabila surat atau bukti tersebut pada saat pemeriksaan tidak dapat ditemukan. Artinya bahwa novum tersebut ada sebelum perkara tersebut diperiksa. Novum yang diajukan dalam kedua putusan tersebut sama-sama merupakan putusan Mahkamah Agung yang muncul jauh setelah perkara diperiksa. Majelis 
hakim dalam Putusan Nomor 119PK/Pdt.SusHKI/2017 tidak menilai waktu munculnya novum yang diajukan yang penting bersifat menentukan dan diterima sebagai novum, sedangkan dalam Putusan Nomor 104PK/Pid.Sus/2014 majelis hakim menilai waktu munculnya novum yang diajukan, sehingga tidak menilai apakah novum tersebut bersifat menentukan atau tidak dan tidak diterima sebagai novum.

Suatu putusan peninjauan kembali perkara pidana ataupun sebaliknya tidak dapat diajukan novum dalam peninjauan kembali sebagaimana disebutkan dalam Pasal 67 huruf $b$ dan huruf e Undang-Undang Nomor 14 Tahun 1985 tentang Mahkamah Agung. Hal ini dikarenakan sesuai dengan Pasal 67 huruf b bahwa suatu surat bukti dapat dijadikan novum harus bukti yang ditemukan setelah perkara berkekuatan hukum tetap baru bukti tersebut ditemukan, dan keberadaan bukti tersebut telah ada sebelum perkara mulai dilakukan pemeriksaan.

Pengajuan putusan peninjauan kembali jelas-jelas tidak memenuhi syarat tersebut, karena sudah dapat dipastikan bahwa putusan peninjauan kembali baru ada setelah suatu perkara mulai dilakukan pemeriksaan. Demikian juga, jika mengacu kepada alasan yang diatur dalam Pasal 67 huruf e bahwa pertentangan antara satu putusan dengan putusan yang lain dipersyaratkan harus yang sama pengadilan atau sama tingkatannya. Putusan peninjauan kembali tentunya tidak setingkat dengan putusan kasasi, putusan banding, dan putusan pertama. Oleh karena itu, tidak bisa dipertentangkan antara putusan peninjauan kembali dengan putusan kasasi, putusan banding, dan putusan tingkat pertama.

\section{DAFTAR ACUAN}

Arto, A.M. (2018). Upaya hukum kasasi \& peninjauan kembali perkara perdata agama, ekonomi syariah, \& jinayah. Depok: Kencana.

Casavera. (2009). 15 kasus sengketa merek di Indonesia. Yogyakarta: Graha Ilmu.

Chazawi, A. (2011). Lembaga peninjauan kembali (PK) perkara pidana; Penegakan hukum dalam penyimpangan praktik \& peradilan sesat. Jakarta: Sinar Grafika.

Dianggoro, W. (1997). Pembaharuan UndangUndang Merek \& dampaknya bagi dunia bisnis. Jakarta: Yayasan Perkembangan Hukum Bisnis.

Djumhana, M., \& Djubaedillah, R. (2003). Hak milik intelektual sejarah, teori, \& prakteknya di Indonesia. Bandung: Citra Aditya Bakti.

Gautama, S. (1987). Hukum merek Indonesia. Bandung: Alumni.

Harahap, M.Y. (2008). Kekuasaan Mahkamah Agung; Pemeriksaan kasasi \& peninjauan kembali perkara perdata. Jakarta: Sinar Grafika.

Hariyani, I. (2010). Prosedur mengurus HAKI yang benar. Yogyakarta: Pustaka Yustisia.

Mardianto, A. (2010, Januari). Penghapusan pendaftaran merek berdasarkan gugatan pihak ketiga. Jurnal Dinamika Hukum, 10(1), 43-50.

Marzuki, P.M. (2011). Penelitian hukum. Jakarta: Prenada Media Group.

Maulana, I.B. (1999). Perlindungan merek terkenal di Indonesia dari masa ke masa. Bandung: Citra Aditya Bakti.

Muhammad, A.K. (1986). Hukum acara perdata Indonesia. Bandung: Alumni.

News.detik.com. (2016). Gudang Garam vs 
Gudang Baru bukan menjiplak tapi Ali tetap dipenjara. Diakses dari https://news.detik.com/ berita/3254190/gudang-garam-vs-gudang-barubukan-menjiplak-tapi-ali-tetap-dipenjara.

Ramli, A.M. (2004). Cyber Law \& HAKI dalam sistem hukum Indonesia. Bandung: Refika Aditama.

Saidin, O.K. (2006). Aspek hukum kekayaan intelektual (Intellectual property rights). Jakarta: Raja Grafindo Persada.

Sembiring, S. (2002). Prosedur \& tata cara memperoleh hak kekayaan intelektual di bidang hak cipta paten \& merek. Bandung: Yrama Widya.

Soekanto, S., \& Mamudji, S. (2009). Penelitian hukum normatif; Suatu tinjauan singkat. Jakarta: Raja Grafindo Persada.

Sulistiyono, A. (2004). Mekanisme penyelesaian sengketa hak atas kekayaan intelektual. Surakarta: Sebelas Maret University Press.

Susanto, A.B., \& Wijanarko, H. (2004). Power branding; Membangun merek unggul \& organisasi pendukungnya. Jakarta: Mizan Publika.

Sutantio, R.W., \& Winata, I.U. (1983). Hukum acara perdata dalam teori \& praktek. Bandung: Alumni.

Sutjipto, M.N.P. (1984). Pengertian pokok-pokok hukum dagang Indonesia. Jakarta: Djambatan.

Tjiptono, F. (2005). Brand management \& strategy. Yogyakarta: Andi.

Usman, R. (2003). Hukum hak atas kekayaan intelektual, perlindungan \& dimensi hukumnya di Indonesia. Bandung: Alumni.

WIPO. (2008). Membuat sebuah merek; Pengantar merek untuk usaha kecil \& menengah. Jakarta: WIPO. 